\title{
Flood Damage Assessment Using River Water Levels - A Case Study of a Town Located in the North Mazovian Lowland (Poland)
}

\author{
Robert Muszyński ${ }^{1}$, Katarzyna Kocur-Bera ${ }^{{ }^{*}}$ \\ 1 University of Warmia and Mazury in Olsztyn, Faculty of Geoengineering, Institute of Geodesy and Civil \\ Engineering, ul. M. Oczapowskiego 2, 10-719 Olsztyn, Poland \\ * Corresponding author's e-mail: katarzyna.kocur@uwm.edu.pl
}

\begin{abstract}
Flooding is a very dangerous phenomenon, causing both direct and indirect damage. The preventive actions result from the awareness of the danger and consequences of floods. In the affected areas, an important stage of management includes preventing and minimizing losses. The article presents a method for estimating the flood losses using flood hazard maps and taking into account the updated prices. Particular emphasis was placed on different risk levels of risk that are due to a flood in the examined location. The analysis was performed for the city through which three rivers flow. The generally available flood hazard maps in the Computerized National Protection System (Polish acr. ISOK), which include the information on the depth of the floodwater and land use classes, help estimate the financial losses. The research has shown that the greatest material losses caused by flooding are usually incurred in residential areas. On the basis of the results obtained, it was also determined that asset revaluation with time has a significant impact on the level of estimated losses. The article uses the methodology implemented in the Flood Risk Maps, which present the negative consequences for the population and the scope of flood losses. The results were compared with the author's interpretation.
\end{abstract}

Keywords: floods, flood hazard maps, flood risk maps, financial losses

\section{INTRODUCTION}

Flood is a dangerous phenomenon that causes enormous financial and other damages (Borowska-Stefańska, 2015b). In the affected area, it is thus extremely important to anticipate and counteract the possible consequences of floods, minimising losses (Messner et al., 2005; Wałęga, 2014).

Historically, humans commonly settled in river valleys (Mihu-Pintilie et al., 2019; Grežo et al., 2020). Owing to fertile soils, not threatened by drought, these places enabled the development of agriculture. The productivity of soils in the river valleys was high, which reduced the expenditures on fertilization and irrigation of crops. Farmers were forced to protect their crops from flooding and to accept the losses that occurred after the flood. Today, such locations are still often used for farming, but excessive urbanization forces investors to estimate the extent of possible financial losses (Grežo et al., 2020). Profitability calculations for undertaking and monitoring the safety levels become crucial in making the location-related decisions.

Transformation of the natural hydrological system using technical methods, to adapt the land for investment, significantly changes the natural conditions. On the other hand, adaptation to the prevailing natural conditions is often equivalent to accepting the consequences of floods. It is only possible to eliminate them through efficient management and monitoring of the frequently flooded areas. This was popular as early as in the Middle Ages. Apart from active protection, e.g. construction of dikes, our ancestors also used passive protection in the form of prediction and adaptation to water levels (Schulz, 2008).

A flood is most often a consequence of the conflict between nature and man who exploits the 
flooded areas. The type, extent, and size of the damage are related to the infrastructural development and actions society has taken to avoid losses. In terms of the destroyed or lost goods, flood damages affect people, animals, cultural heritage, the environment, industrial and agricultural production as well as municipal infrastructure. Intangible losses are often overlooked because their presence is considered negligible and their valuation is problematic. Therefore, the notion of the loss/damage function (Kocur-Bera, 2017, 2019) is the overriding idea in the estimation of the financial flood losses. It is related to the dependence on the method of land use/building and the depth of floodwater.

In general, in the areas with extensive investments, such as cities, the flood risk is greater. These areas are characterized by strongly sealed terrain surfaces such as roads, car parks, and other hard surfaces. The infiltration capacity decreases, which contributes to pluvial floods in case of heavy rainfall (Schultz, 2008; Szeląg et al., 2019). In extreme cases, due to high investment risk, floods lead to underdevelopment of some urban areas (Smith et al., 1998). The increasing availability of the data on floods and their consequences allows for applying the measures mitigating these consequences. Important aspects are not limited to engineering and hydraulics of flood prevention, but also include the ecological, political, or socio-economic issues. In cities, proper flood risk management constitutes an important aspect of minimising the flood losses (Wałęga et al., 2014).

Flood risk assessment is a complex procedure enabling to identify both the flood-related and urbanisation-related risks (Smith et al., 2015; Sowiński, 2008). When determining the risk, hydrological and hydraulic flood models are very important (Schultz, 2008). Taking into account the climate variability, land development and land use, it is possible to determine the probability of the occurrence of a given threat and the amount of losses that it entails. The model provides us with the information on the flood zone range and water depth, as well as the duration and speed of flow (Gutry-Korycka et al., 2014). With this information, for locations with different development modes, it is possible to determine the areas bearing the greatest flood risk and the greatest material losses. This information allows for taking the actions to minimize the flood consequences. Currently, there are many different methods to assess the material flood losses. Their diversity results from the methods used in specific countries and the very character of floods. Flood characteristics and scenarios, the type, number and location of the exposed infrastructure elements, the real-estate value and sensitivity of its components to a flood (determined by the flood losses function) constitute the most common basis for the estimation of flood losses (Messner et al., 2005). In the model for estimating the financial losses, a flood can be characterized by the surface area (Behnen et al., 2000; Ebenhöh et al., 1997), the depth and duration (the time until water withdraws back to the river-bed) and the water flow velocity (Satrapa et al., 2005; Èihák et al., 2005). It is possible to determine the flood losses by linking the data on land use, floodwater depth, as well as property value and its sensitivity to flooding (Buczek et al., 2011).

This paper aimed to examine the amount of losses that may occur during a flood, using a method including time lapse. The flood hazard maps and flood risk maps made available under the ISOK project (Computerized National Protection System) were used for the analyses.

\section{MATERIALS AND METHODS}

\section{Description of the research area}

The analysed area lies in the Mazowieckie Voivodeship, in the southern part of the city of Ostrołęka. The area under analysis is located in north-eastern Poland in the North-Mazovian Lowland (see figure 1). The studied city is located in the central part of the district. Its population is over 52,000, surface area $33.6 \mathrm{~km}^{2}$ (GUS, 2018). Three rivers (Narew, Omulew and Czeczotka Rivers) flow through the city. The Narew River is a right tributary of the Vistula, its length being $484 \mathrm{~km}$. On the western side of the Narew River, there is a floodbank protecting the city of Ostrołęka.

The studied area covers 516 ha, 167.4 ha of which are at risk of flooding. The largest part of the studied area is covered by grassland (38.7\%) and forests (33.8\%). There are also industrial areas $(2.7 \%)$, residential developments $(14.9 \%)$, arable land (7.6\%), and traffic areas (2.3\%). Figure 2 presents the structure of land use. 


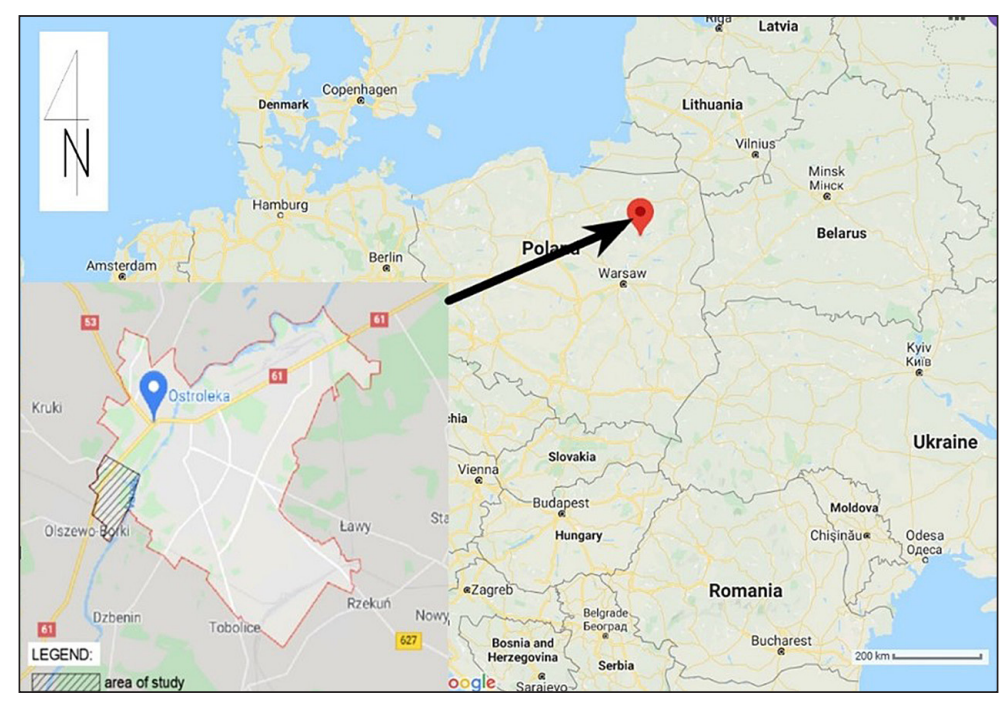

Figure 1. Location of the studied area.

\section{Methods}

The realization of research objectives in the selected area consisted in identification of possible negative consequences resulting from the occurrence of floods in the southern part of the city of Ostrołęka. The flood hazard maps with water depth and two types of flood risk maps. These maps were developed by IMiGW (Institute of Meteorology and Water Management) in the ISOK project (Computerized National Protection System) for the areas where the probability of floods is average, i.e. once every 100 years (Q $1 \%$ ) (ISOK, 2020). On the basis of the flood risk map, the management methods for the endangered areas were determined, the land use classes were distinguished and their surface area was calculated. Another layer was then fitted into the map: a flood hazard map with water depths, thus obtaining floodplains with water levels of (a) $\mathrm{h} \leq 0.5 \mathrm{~m}$; (b) $0.5<\mathrm{h} \leq 2.0 \mathrm{~m}$; (c) $2.0<\mathrm{h} \leq 4.0 \mathrm{~m}$. The flood risk maps were used to compare the potential flood losses determined in these intervals with the results of the conducted analysis (Appendix A). The procedures followed during research are shown in Figure 3.

The valuation of material losses was based on the guidelines contained in Regulation (Act of 21 November 2012 on the development of flood risk maps and flood risk maps), using the following principles:

1. The sum of individual flood loss values for all land use classes in the area is calculated using formula (1):

$$
\boldsymbol{S} \boldsymbol{p}_{\boldsymbol{i}}=\sum_{j=1}^{4} S p_{i j} \times A_{i} \text { dla } i=1 . .9
$$

where: $S p_{i}$ - total value of estimated individual losses for a specific land-use class,

\section{Percentage share od land classes in flood risk areas}

2,3

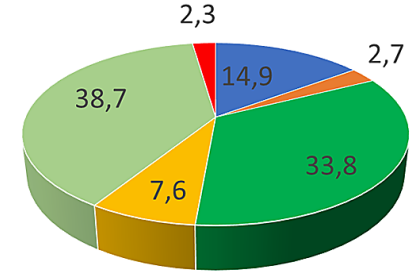

- residential development areas $\square$ industrial areas

- forests $\quad$ arable land

grassland $\quad$ communication areas

Figure 2. Structure of land use in the research area. 
$S p_{i j}$ - the value of estimated individual losses for a specific land-use class and a specific water depth range,

$A_{i}$ - surface area of a specific land-use class.

2. For residential areas, industrial areas, and traffic areas, the final value of the estimated flood losses is obtained by comparing the value of a property for a given class of land use with the degree of property loss, which depends on the depth of floodwater. The loss function is calculated using formula (2):

$$
\boldsymbol{S} \boldsymbol{p}_{\boldsymbol{i j}}=W_{i} \times f(h)_{j}
$$

where: $S p_{i j}$ - the value of estimated individual losses for a specific land-use class and a specific water depth range,

$W_{i}$ - property value in a specific land-use class,

$f\left(h_{j}\right)$ - the value of the loss function depending on the water level in a specific land-use class;

3. For recreation and leisure areas, forests, and agricultural land (arable land and grassland), the same loss values apply regardless of the water depth.

4. Losses are not determined for waters and other areas.

The loss function (amount of property loss) is determined for the water depth ranges limits. The values of the loss function in particular land use classes according to regulation are calculated using the formula (3):

$$
\boldsymbol{S} \boldsymbol{p}_{\boldsymbol{i}}=\sum_{j=1}^{4} S p_{i j} \times A_{i} \text { dla } i=1 . .9
$$

where: $S p_{i}$ - total value of estimated individual losses for a specific land-use class, $S p_{i j}$ - the value of estimated individual losses for a specific land-use class and a specific water depth range,

$A_{i}$ - surface area of a specific land-use class.

5. For residential areas, industrial areas, and traffic areas, the final value of estimated flood losses is obtained by comparing the value of a property for a given class of land use with the degree of property loss, which depends on the depth of floodwater. The loss function is calculated using formula (2):

$$
\boldsymbol{S} \boldsymbol{p}_{\boldsymbol{i j}}=W_{i} \times f(h)_{j}
$$

where: $S p_{i j}$ - the value of estimated individual losses for a specific land-use class and a specific water depth range,

$W_{i}$ - property value in a specific land-use class,

$f\left(h_{j}\right)$ - the value of the loss function depending on the water level in a specific land-use class.

6. For recreation and leisure areas, forests, and agricultural land (arable land and grassland), the same loss values apply regardless of the water depth, as the water levels do not influence the amount of losses in these use classes.

7. Losses are not calculated for waters and other areas.

\section{Determination of land management methods in the affected area}

\section{Distinguishing land-use classes}

\section{Calculation of surface area for each use class}

Integration of the usage classes map with the map of floodwater level ranges

Update of losses due to the passage of time

Estimation of losses in the affected area taking into account the passage of time

\section{Comparison of the estimated values of flood losses}

Figure 3. Diagram of research methodology. 
The values of the loss function in particular land use classes are presented in Table 1.

8. Property value in particular land use classes is assumed to be:

- traffic areas - $97 \mathrm{EUR} / \mathrm{m}^{2}$.

- forests - $18 \mathrm{EUR} / \mathrm{ha}$.

- recreational and leisure areas $-1.1 \mathrm{EUR} / \mathrm{m}^{2}$.

- arable land - 317.3 EUR/ha.

- grassland - 149.8 EUR/ha.

- for residential and industrial areas, the value depends on the location, according to the administrative division of the country (see Table 2).

With the information on three components, i.e. unit value of assets, water depth, and land use, it is possible to calculate the potential material losses [EUR]. The asset valuation method was based on the German practices. Since the prices of property and other assets are subject to fluctuations in time, information updates are needed. The provisions of law do not regulate it, but indicate how it should be updated. The method proposed by Borowska-Stefańska (2015) was used in this paper.

It assumes that the property value update can be based on the change in the consumer price index (expressed in inflation). However, for industrial areas, the price index for sold produced goods (for the industry) as well as assembly and construction (construction industry) should be used. In addition, for these areas, the index should be increased by the share of current assets that may be lost/decommissioned during flooding. The ratio of current assets to fixed assets ratio determined for the public statistics purposes was used for analysis (in 2019 it was 0.15 ). The amount of the updated value of housing development was calculated on the basis of the changes in the price index of goods and services in recent years. In the years 2008-2019, according to the statistics of the Central Statistical Office (BDL, 2020), there was an increase in prices.

The value of losses caused by flooding in the areas used for agriculture was set in the regulation at the level of $317.33 \mathrm{EUR} / \mathrm{ha}$ for arable land and 149.78 EUR/ha for grassland. These indicators were developed on the basis of the German indicators from 2008, which are the same for the whole country, without division into voivodeships, as opposed to the
Table 1. Value of property value in individual land use classes,

\begin{tabular}{|c|c|c|c|}
\hline \multirow{2}{*}{ Water level [m] } & \multicolumn{3}{|c|}{ Value of the loss function $\mathrm{f}(\mathrm{h})[\%]$} \\
\cline { 2 - 4 } & $\begin{array}{c}\text { residential } \\
\text { areas }\end{array}$ & $\begin{array}{c}\text { industrial } \\
\text { areas }\end{array}$ & $\begin{array}{c}\text { traffic } \\
\text { areas }\end{array}$ \\
\hline $\mathrm{h} \leq 0.5$ & 20 & 20 & 5 \\
\hline $0.5<\mathrm{h} \leq 2.0$ & 35 & 40 & 10 \\
\hline $2.0<\mathrm{h} \leq 4.0$ & 60 & 60 & 10 \\
\hline$>4.0$ & 95 & 80 & 10 \\
\hline
\end{tabular}

Table 2. Value of assets in residential and industrial areas for the studied area (Masovian Voivodeship)

\begin{tabular}{|c|c|c|}
\hline Region & $\begin{array}{c}\text { Value for residential } \\
\left.\text { areas [EUR/m } / \mathrm{m}^{2}\right]\end{array}$ & $\begin{array}{c}\text { Value for } \\
\text { industrial areas } \\
{\left[\mathrm{EUR} / \mathrm{m}^{2}\right]}\end{array}$ \\
\hline Masovian & 113.25 & 209.74 \\
\hline
\end{tabular}

indicators in residential and industrial areas. The specificity of agricultural production was not taken into account when determining the indicators. The type of crops should be taken into account when estimating the flood losses. Underestimating the losses will be significant for specialized agricultural production, for example: tobacco, rape, vegetables or horticulture (Green, 2003). Due to the crop rotation used in agriculture, this study also does not take into account the type of crop. However, when determining the index, the value of losses on arable land and grassland was updated due to the increasing value of the agricultural production index over time. On the basis of Central Statistical Office (GUS, 2020), the production values per hectare in a given year were calculated. Due to the changing prices and yields in individual years (e.g. due to the weather conditions), an average of 3 years was adopted for the analysis. The current ratio (2017-2019) of agricultural production per hectare in relation to the values from $2007-2009$ is 34\% higher for arable land and 20\% higher for grassland. If the production index increased, the losses in agricultural production areas will also increase proportionally.

In forest areas and communication areas, it is difficult to determine the amount of damage caused by the flood. Prices can be updated using the index of consumer prices and services expressed in inflation. In this way, the obtained results will reflect the reality more closely (Borowska-Stefańska, 2015). 


\section{RESULTS}

Regulation of 2012 on the development of flood hazard maps and flood risk maps transparently presents the calculation of the value of potential flood losses in individual land use classes. The methodology which depends on the water depth and the type of land use was used in Germany. However, it is already a relatively old document, which based the calculated values on the data from 2008. There is also no information about their update; therefore, this study presents the results of the update.

The amount of the updated value of residential buildings was calculated on the basis of GUS statistical data (BDL, 2020) and presented in Table 3. Originally, this value was $113.25 \mathrm{EUR} / \mathrm{m}^{2}$. On the basis of the available data, this value was updated to 2019. The updated value of losses of $1 \mathrm{~m}^{2}$ of residential development is 135.35 EUR. It is $19.5 \%$ higher than the value specified in the regulation.

In the case of residential areas (see table 4), the value of financial losses caused by the flood for individual water depths and the updated value of the property totaled 11.24 million EUR. In the analyzed area, the flood risk maps do not predict the occurrence of floods with a water level above $2 \mathrm{~m}$. It is estimated that the water level will not exceed $0.5 \mathrm{~m}$ in about $10 \%$ of the area of residential buildings. In the remaining part, the depth of flooding water is $0.5-2 \mathrm{~m}$. According to the ordinance of 2012, the losses for residential development areas amount to $20 \%$ of the total estimated value for the flood water height below $0.5 \mathrm{~m}$; for greater depths in the range of $0.5-2 \mathrm{~m}$, these losses are up to $35 \%$. Table 4 presents a summary of the values in individual areas and the amount of losses was calculated.

The price level change index from 2008 to 2019 for fixed assets (for industrial areas) was 1.166, the ratio of current assets to fixed assets is 0.15 (GUS, 2020). The updated value of industrial assets (fixed assets and current assets) amounted to $281.24 \mathrm{EUR} / \mathrm{m}^{2}$. This is a $34 \%$ increase in value compared to the prices set in the regulation. In order to estimate the total value of flood losses in industrial areas, the depth of floodwater, on which the amount of these losses depends, should be taken into account. In industrial areas, as in residential areas, the flood risk maps do not provide for a floodwater depth of more than $2 \mathrm{~m}$. According to the 2012 regulation, for a flood water height of less than $0.5 \mathrm{~m}$, losses amount to $20 \%$ of the total value, and for greater depths in in the range of $0.5-2 \mathrm{~m}-$ at the level of $40 \%$ of the total value. The total value of losses in the study area within industrial sites is approximately 4.3 million EUR. The average value of losses is 945 thousand EUR/ ha. It is estimated that in about $70 \%$ of the area, the depth of flooding water will be from $0.5-2 \mathrm{~m}$, in the remaining area it will not exceed $0.5 \mathrm{~m}$. Table 5 presents the financial values of flood losses in industrial areas, including the water depth.

In the areas used for agriculture (meadows, pastures, arable lands) and in forest areas, the amount of flood losses does not depend on the water depth. The losses caused by the occurrence of a flood are directly proportional to the surface area of the flooded area. The value of flood losses in agricultural areas has been updated on the basis of the agricultural production index per 1 ha. As a result of the analysis, it was calculated that the value of agricultural production for arable land from 2008 compared to 2019 increased by $33.8 \%$, while on grassland - by $20.2 \%$. Using these indicators, the values of the flood losses can be updated (Borowska-Stefańska, 2015). If the value of production is higher, the losses of this production will also be proportionally greater. The results of the calculations are presented in Table 6 . Thus, the updated loss values for arable land are 425.22 EUR/ha and for grassland 179.74 EUR/ha.

Using the calculated ratios, it is possible to calculate the value of losses in agricultural lands. And so, on arable land, according to the regulation, the value of losses is $317.3 \mathrm{EUR} / \mathrm{ha}$ (2008), while after conversion for 2019 , this value is

Table 3. Price indices for a given year in relation to the previous year and the updated residential development value

\begin{tabular}{|c|c|c|c|c|c|c|c|c|c|c|c|}
\hline $\begin{array}{c}\text { Value of } \\
\text { assets } \\
\text { according to } \\
{[23]}\end{array}$ & 2009 & 2010 & 2011 & 2012 & 2013 & 2014 & 2015 & 2016 & 2017 & 2018 & 2019 \\
\cline { 2 - 11 }$y$ & 103.4 & 102.4 & 103.7 & 103.5 & 100.8 & 100.0 & 99.1 & 99.5 & 101.9 & 101.6 & 102.2 \\
\hline \multirow{2}{*}{\begin{tabular}{c}
113.25 [EUR] \\
\cline { 2 - 11 }
\end{tabular}} & 117.13 & 119.91 & 124.35 & 128.70 & 129.73 & 129.73 & 128.56 & 127.92 & 130.35 & 132.44 & 135.35 \\
\hline
\end{tabular}


Table 4. Value of losses [EUR] in the residential areas in the studied area

\begin{tabular}{|c|c|c|c|c|c|}
\hline \multirow{2}{*}{ Land number } & \multicolumn{3}{|c|}{ Surface area broken down in water levels } & \multirow{2}{*}{ Total surface area } & \multirow{2}{*}{$\begin{array}{c}\text { Value of losses } \\
\text { [EUR] }\end{array}$} \\
\hline & $\mathrm{h} \leq 0.5[\mathrm{~m}]$ & $0.5<\mathrm{h} \leq 2.0[\mathrm{~m}]$ & $2.0<\mathrm{h} \leq 4.0[\mathrm{~m}]$ & & \\
\hline B1 & 0.2545 & - & - & 0.2545 & 68893.15 \\
\hline B2 & 0.0831 & 1.4662 & - & 1.5493 & 717067.765 \\
\hline B3 & 0.8118 & - & - & 0.8118 & 219754.26 \\
\hline B4 & 0.6495 & - & - & 0.6495 & 175819.65 \\
\hline B5 & 0.1746 & - & - & 0.1746 & 47264.22 \\
\hline B6 & 0.6443 & - & - & 0.6443 & 174412.01 \\
\hline B7 & - & 0.4621 & - & 0.4621 & 218908.323 \\
\hline B8 & - & 0.9207 & - & 0.9207 & 436158.608 \\
\hline B9 & - & 1.2225 & - & 1.2225 & 579128.813 \\
\hline B10 & - & 15.9097 & - & 15.9097 & 7536822.63 \\
\hline B11 & - & 0.3677 & - & 0.3677 & 174188.683 \\
\hline B12 & 0.1242 & 0.9817 & - & 1.1059 & 498676.773 \\
\hline B13 & - & 0.8350 & - & 0.8350 & 395560.371 \\
\hline Total & 2.7420 & 22.1656 & 0.0000 & 24.9076 & 11242655.26 \\
\hline \multicolumn{6}{|c|}{ The amount of losses in industrial areas } \\
\hline Loss value & $\begin{array}{c}20 \% \text { of } \\
135.35 \text { EUR/m } / \mathrm{m}^{2}\end{array}$ & $\begin{array}{c}35 \% \text { of } \\
135.35 \mathrm{EUR} / \mathrm{m}^{2}\end{array}$ & $\begin{array}{c}60 \% \text { of } \\
135.35 \mathrm{EUR} / \mathrm{m}^{2} \\
\end{array}$ & & \\
\hline Total losses & 742256.40 & 10500398.86 & 0.00 & & 11242655.26 \\
\hline
\end{tabular}

Table 5. Value of losses [EUR] in industrial areas, including the studied area

\begin{tabular}{|c|c|c|c|c|c|}
\hline \multirow{2}{*}{ Land number } & \multicolumn{3}{|c|}{ Surface area broken down in water levels } & \multirow{2}{*}{$\begin{array}{c}\text { Total surface } \\
\text { area }\end{array}$} & \multirow{2}{*}{$\begin{array}{c}\text { Value of losses } \\
\text { [EUR] }\end{array}$} \\
\hline & $\mathrm{h} \leq 0.5[\mathrm{~m}]$ & $0.5<\mathrm{h} \leq 2.0[\mathrm{~m}]$ & $2.0<\mathrm{h} \leq 4.0[\mathrm{~m}]$ & & \\
\hline Ba 1 & 0.8901 & 0.9031 & & 1.7932 & 1520389.27 \\
\hline $\mathrm{Ba} 2$ & 0.5954 & 0.7264 & & 1.3218 & 1154939.02 \\
\hline Ba 3 & & 0.6231 & & 0.6231 & 702707.26 \\
\hline Ba 4 & & 0.845 & & 0.845 & 952957.20 \\
\hline TOTAL & 1.4855 & 3.0976 & 0.0000 & 4.5831 & 4330992.75 \\
\hline \multicolumn{6}{|c|}{ The amount of losses in industrial areas } \\
\hline Loss value & $\begin{array}{c}20 \% \text { of } \\
281.94 \text { EUR } / \mathrm{m}^{2}\end{array}$ & $\begin{array}{c}40 \% \text { of } \\
281.94 \text { EUR/m² }\end{array}$ & $\begin{array}{c}60 \% \text { of } \\
281.94 \mathrm{EUR} / \mathrm{m}^{2}\end{array}$ & & \\
\hline Total losses & 837643.37 & 3493349.38 & 0.00 & & 4330992.75 \\
\hline
\end{tabular}

Table 6. Calculated agricultural production index in particular years

\begin{tabular}{|c|c|c|c|c|c|c|c|c|c|}
\hline \multicolumn{10}{|c|}{ Agricultural production index } \\
\hline Year & 2007 & 2008 & 2009 & 2010 & $\ldots$ & 2016 & 2017 & 2018 & 2019 \\
\hline Cereal: yields per 1 ha [dt] & 32.5 & 32.2 & 34.8 & 35.6 & $\ldots$ & 40.0 & 42.0 & 34.3 & 36.7 \\
\hline Grassland: yields per 1 ha [dt] & 51.7 & 48.3 & 49.2 & 49.0 & $\ldots$ & 52.4 & 54.2 & 46.3 & 44.6 \\
\hline Price per dt of wheat [EUR] & 16.89 & 18.40 & 12.73 & 14.42 & $\ldots$ & 16.69 & 17.52 & 18.58 & 20.36 \\
\hline Price pre dt of hay [EUR] & 7.65 & 7.97 & 7.75 & 9.11 & $\ldots$ & 8.72 & 8.78 & 9.73 & 10.54 \\
\hline \multicolumn{10}{|c|}{ Calculated agricultural production indices [EUR/ha] } \\
\hline Arable land & 548.96 & 592.62 & 443.12 & 513.51 & $\ldots$ & 667.64 & 736.03 & 637.45 & 747.29 \\
\hline Grassland & 395.68 & 384.90 & 381.14 & 446.44 & $\ldots$ & 456.93 & 475.76 & 450.45 & 470.28 \\
\hline Average areable land & \multicolumn{3}{|c|}{ 528.23 EUR/ha } & \multirow{2}{*}{\multicolumn{3}{|c|}{$\cdots$}} & \multicolumn{3}{|c|}{ 706.92 EUR/ha } \\
\hline Average grassland & \multicolumn{3}{|c|}{ 387.24 EUR/ha } & & & & \multicolumn{3}{|c|}{$465.50 \mathrm{EUR} / \mathrm{ha}$} \\
\hline
\end{tabular}


424.55 EUR / ha. On grassland, the value of losses according to the regulation was $150 \mathrm{EUR} / \mathrm{ha}$, after updating this value increased by $20.2 \%$ and amounts to $180.30 \mathrm{EUR} / \mathrm{h}$.

In forest areas and traffic areas, the change in the amount of losses due to the passage of time was calculated using the index of consumer prices and services, expressed as inflation. In this way, the obtained results are more relevant to reality. Inflation against 2008, according to the GUS statistics, was $19.5 \%$. Flooding in forest areas does not cause large losses. The updated values of losses in forest areas at the end of 2019 are 21.24 EUR/ha.

Water depth is also important in the communication areas; therefore, the losses were calculated taking into account the depth of floodwater. According to the flood hazard map, in the studied area, there is flood water in communication areas in the ranges $\mathrm{h} \leq 0.5$ and $0.5<\mathrm{h} \leq 2.0 \mathrm{~m}$. For a floodwater height of less than $0.5 \mathrm{~m}$, the losses are at the level of $5 \%$ of the total value, and for greater depths - at the level of $10 \%$ of the total value. The updated value of losses caused by flooding in communication areas is $115.92 \mathrm{EUR} / \mathrm{m}^{2}$ (Table 7)
Table 8 presents the total estimated financial losses due to the floods for the analyzed area. The large share of forests (almost 34\% of the studied area) contributed to the reduction of the total value of losses. In agricultural areas (arable land and grassland), the losses are also relatively low. In total, agricultural land covers about $46 \%$ of the total area, and its share in the total value of losses is only $0.11 \%$. The greatest losses are generated by built-up areas (industrial and residential). These areas cover a total of about $18 \%$ of the area, but the estimated losses in these areas constitute $97.75 \%$. In the area at risk of flooding, the estimated losses amounted to almost 16 million EUR. The average loss per hectare is 95190 EUR. As can be seen in the table below, after updating the prices from the regulation from 2012 , the value of losses in the examined area increased by $23 \%$, compared to 2019 .

In the further part of the analyses, the obtained results were compared with the potential losses presented on the flood risk map (areas with an average probability of flooding once every 100 years) from the ISOK project (see Appendix A. In order to calculate the amount of

Table 7. Value of losses [EUR] in communication areas, taking into account the area of the studied area

\begin{tabular}{|c|c|c|c|}
\hline \multirow{2}{*}{ Land number } & \multicolumn{2}{|c|}{ Surface area broken down in water levels } & \multirow{2}{*}{ Total surface } \\
\cline { 2 - 4 } & $\mathrm{h} \leq 0.5[\mathrm{~m}]$ & $0.5<\mathrm{h} \leq 2.0[\mathrm{~m}]$ & 1342 \\
\hline $\mathrm{dr} 1$ & 7602 & & 1695 \\
\hline $\mathrm{dr} 2$ & 1665 & 1254 & 4403 \\
\hline $\mathrm{dr} 3$ & 3149 & 16935 & 21169 \\
\hline $\mathrm{dr} 4$ & 4234 & & 3108 \\
\hline $\mathrm{dr} 5$ & 3108 & 19531 & 39289 \\
\hline Total & 19758 & $10 \%$ of & $115.92 \mathrm{EUR} / \mathrm{m}^{2}$ \\
\hline
\end{tabular}

Table 8. Value of losses in [EUR] in the study area

\begin{tabular}{|c|c|c|c|c|c|}
\hline \multicolumn{6}{|c|}{ Breakdown of total estimated flood losses } \\
\hline \multirow[t]{2}{*}{ Type of use } & \multirow{2}{*}{$\begin{array}{c}\text { Total surface area } \\
\text { [ha] }\end{array}$} & \multicolumn{2}{|c|}{$\begin{array}{l}\text { Value of losses using the indicators } \\
\text { from the regulation }\end{array}$} & \multicolumn{2}{|c|}{$\begin{array}{l}\text { Updated value of losses at the end of } \\
\qquad 2019\end{array}$} \\
\hline & & Index value & Total value & Index value & Total value \\
\hline Residential areas & 24.9076 & $113.25 \mathrm{EUR} / \mathrm{m}^{2}$ & 9406952.70 & $135.35 \mathrm{EUR} / \mathrm{m}^{2}$ & 11242655.26 \\
\hline Industrial areas & 4.5831 & 209.74 EUR/m² & 3221900.04 & $281.94 \mathrm{EUR} / \mathrm{m}^{2}$ & 4330992.75 \\
\hline Traffic areas & 3.9289 & $97.00 \mathrm{EUR} / \mathrm{m}^{2}$ & 285277 & $115.92 \mathrm{EUR} / \mathrm{m}^{2}$ & 340920.72 \\
\hline Forests & 56.5013 & 18.00 EUR/ha & 1017.02 & 21.24 EUR/ha & 1200.09 \\
\hline Arable land & 12.7399 & 317.30 EUR/ha & 4042.37 & 424.55 EUR/ha & 5408.72 \\
\hline Grassland & 64.7284 & 149.80 EUR/ha & 9696.31 & 180.30 EUR/ha & 11670.53 \\
\hline Total [ha] & 167.3892 & Total [EUR]: & 12928885.44 & Total [EUR]: & 15932848.07 \\
\hline
\end{tabular}


losses shown on the map, the areas of all value ranges were summed up. In the next step, the minimum values (the lowest value of losses in the interval) and the maximum values (the highest value of losses in the interval) of the flood losses in the studied area were estimated, based on Appendix A. The minimum values were calculated as the sum of the products of the area and the lowest value in a given value range. The maximum values are the sum of the products of the area and the highest value in a given range of values. As a result of this analysis, the minimum and maximum values were obtained (Table 9). The values were calculated in the Polish currency [PLN], in accordance with the values from the flood risk map (Appendix A). The results were converted into EUR at the current exchange rate (25.10.2020).

As can be seen from the table above (Table 9), the amount of calculated and updated losses, using the method presented in this study, falls within the range calculated on the basis of the flood hazard maps (Appendix A). The summary comparison of the amount of financial losses estimated on the basis of the legislator's guidelines and with the use of updated indicators due to the passage of time is presented in Table 10 .

The calculated value of the losses in the analyzed area amounts to almost 16 million EUR, while the average value of flood damage calculated on the basis of the regulation and flood risk maps much lower. The difference is over $22 \%$, which means that using the data from the regulation or using the values from the flood risk maps (Appendix A), the values may be understated. As a result, the amount of losses may be underestimated and may not show the actual losses.

\section{DISCUSSION}

The study was aimed at showing the method of calculating flood losses taking into account the time lapse. The indicators for estimating flood losses were established in the regulation of 2012, based on the data from 2008 and do not reflect the current state. A flood hazard map provided a point of departure for the study. With it, it was possible to estimate the losses in the flooded area taking into account the flood water level. The estimated value was related to the current value of assets. The nominal data (Act of 21 November 2012 on the development of flood risk maps and flood risk maps) have been updated. This had a significant impact on the final result. The analysis of flood losses also made excessive urbanization of floodplains salient. The results show that the amount of damage largely depends on reasonable area development and planning.

According to many authors, direct financial losses account for the vast majority of total flood damage (Smith et al., 1998). Currently, there are numerous methods used to assess the material effects of flood damage. These vary slightly, depending on the type of flood and its character. The collection of the information on land use constitutes a very important step in determining the potential damage. In urban areas, this data should be very detailed, as it concerns assets of

Table 9. Summary of losses in individual ranges based on the flood risk map (Appendix A)

\begin{tabular}{|c|c|c|c|c|c|}
\hline \multicolumn{6}{|c|}{ Financial losses ranges in the analysed area } \\
\hline Value ranges & $<1$ PLN & $50,01-100$ & $150,01-300$ & \multirow{2}{*}{$\begin{array}{c}\text { Total value } \\
\text { [PLN] }\end{array}$} & \multirow{2}{*}{$\begin{array}{c}\text { Total value } \\
\text { [EUR] }\end{array}$} \\
\hline Surface area $\left[\mathrm{m}^{2}\right]$ & 1386239 & 32569 & 255084 & & \\
\hline Minimum value & 693120 & 1628775 & 28265151 & 30600545 & 6800121 \\
\hline Maximum value & 1386239 & 3256900 & 76525200 & 81195339 & 18043409 \\
\hline
\end{tabular}

* the minimum values included in the calculations are respectively: 0.50 PLN, 50.01 PLN, 150.01 PLN

** the maximum values included in the calculations are respectively: 1 PLN, 100 PLN, 300 PLN

Table 10. Breakdown of the flood losses in the analysed area

\begin{tabular}{|c|c|c|c|}
\hline \multirow{2}{*}{ Specification } & $\begin{array}{c}\text { Updated value of losses } \\
\text { at the end of } 2019\end{array}$ & $\begin{array}{c}\text { Values calculated based } \\
\text { on flood risk maps }\end{array}$ & $\begin{array}{c}\text { Value of losses using the indicators } \\
\text { from the regulation }\end{array}$ \\
\hline \multirow{2}{*}{ Calculated values } & 15932848,07 & $\min 6800121$ & 12928885,44 \\
\cline { 2 - 3 } & 15932848,07 & $\operatorname{max.} 18043409$ & 12928885,44 \\
\hline
\end{tabular}


high material value. The accuracy of data on the areas used for agriculture (Messner et al., 2005) is not so crucial as it usually concerns large areas of land used in the same way. The loss function, included in the algorithms proposed in legislation, determines the susceptibility of property to particular features of a flood, especially to the flood water level. The time of flooding is also relevant in agriculture. The floods occurring in autumn, after the harvest, entail lower losses than those occurring before the harvest (Green, 2003; DEFRA, 1999). The amount of losses also depends on the type of crops. In the Polish legislation, the method of estimating the potential flood losses is based on a relative loss function. The percentage share in value loss is determined in relation to the flood water level for industrial, residential, and traffic areas. For the remaining areas, no specific percentage ranges for loss were determined, which seems to be an understatement and omission of important data. Directive 2007/60/EC (Directive 2007/60/WE of The European Parliament And of The Council of 23 October 2007 on the assessment and management of flood risks) is the most important legal regulation in Europe on the assessment and management of flood risk. Some countries, e.g. Germany, have developed additional guidelines and instructions on how to determine the flood damage potential and how to select the damage function (e.g. Rhine Atlas - Rheinatlas). In some German regions, such as North RhineWestphalia and Baden-Württemberg, there are guidelines for flood hazard mapping. The asset valuation method used in this study is based on the German practices, but was supplemented by a time update using different measures, depending on the type of property.

The unit losses estimated in this study for residential, traffic, and industrial areas are closely linked to the type of land use, floodwater levels, and unit value of the estimated property. This data enables the estimation of losses expressed in the current currency. However, it should be borne in mind that their comparability and reference to the current conditions depend on data updates, as prices change over time (Chojnacki, 1994).

Currently, all over the world, an increase in floodplains urbanisation can be observed, as mentioned by various studies (Borowska-Stefańska, 2015a; Schanze et al., 2006; Ristic et al., 2012). In Poland, the Water Law (Act of 20 July 2017 water law) that came into force recently, clarified the regulations concerning, among other things, the development conditions in the areas at particular risk of flooding to deter investors from ignoring the flood risks. According to the provisions of this Act, in each commune, it is obligatory to agree on planning documents (commune zoning plan, local zoning plan, decision on development conditions) with an entity appointed by the Minister of the Environment (State Water Management - Polish Waters). Such an obligatory agreement covers the building and development of any piece of real estate fully or partially located in the high flood risk areas.

Local authorities should prevent urbanisation in the high flood risk areas. This will help to achieve the two main objectives of the flood risk management, i.e. to avoid an increase in risk and to minimise the already existing risks, both of them contained in the so-called good practices of flood prevention and mitigation (Best practices on flood prevention, protection and mitigation, 2003). Limiting the expansion of buildings also allows reducing the negative impact of floods on the natural environment. In the high flood risk areas, particular attention should be paid to sustainable management. Unfortunately, the hazards related to the development of flood plains remain underestimated in Poland. When planning and designing buildings located in floodplains, the environment and flood safety are often ignored in the pursuit of developers' interests (Kobojek, 2013; Borowska-Stefańska, 2013; Muszyński, 2018; Ciepielowski, 2003).

\section{CONCLUSIONS}

This study aimed to estimate the potential flood losses in the southern part of Ostrołęka. This area is located in the immediate vicinity of the Narew, Omulew and Czeczotka rivers. On the basis of the analysis of the results obtained in the studied area, it can be confirmed that the flooding brings about enormous material losses. Awareness of the risk and consequences of flooding and taking preventive measures to mitigate its consequences are both of crucial importance.

Two documents were used for the analysis: a flood hazard map and a flood risk map, where the probability of the occurrence of a flood is average and amounts to once every 100 years $(\mathrm{Q} 1 \%)$. The regulation from 2012 was also used, which defines the indicators for estimating the flood losses. When using them, one must be aware of the error 


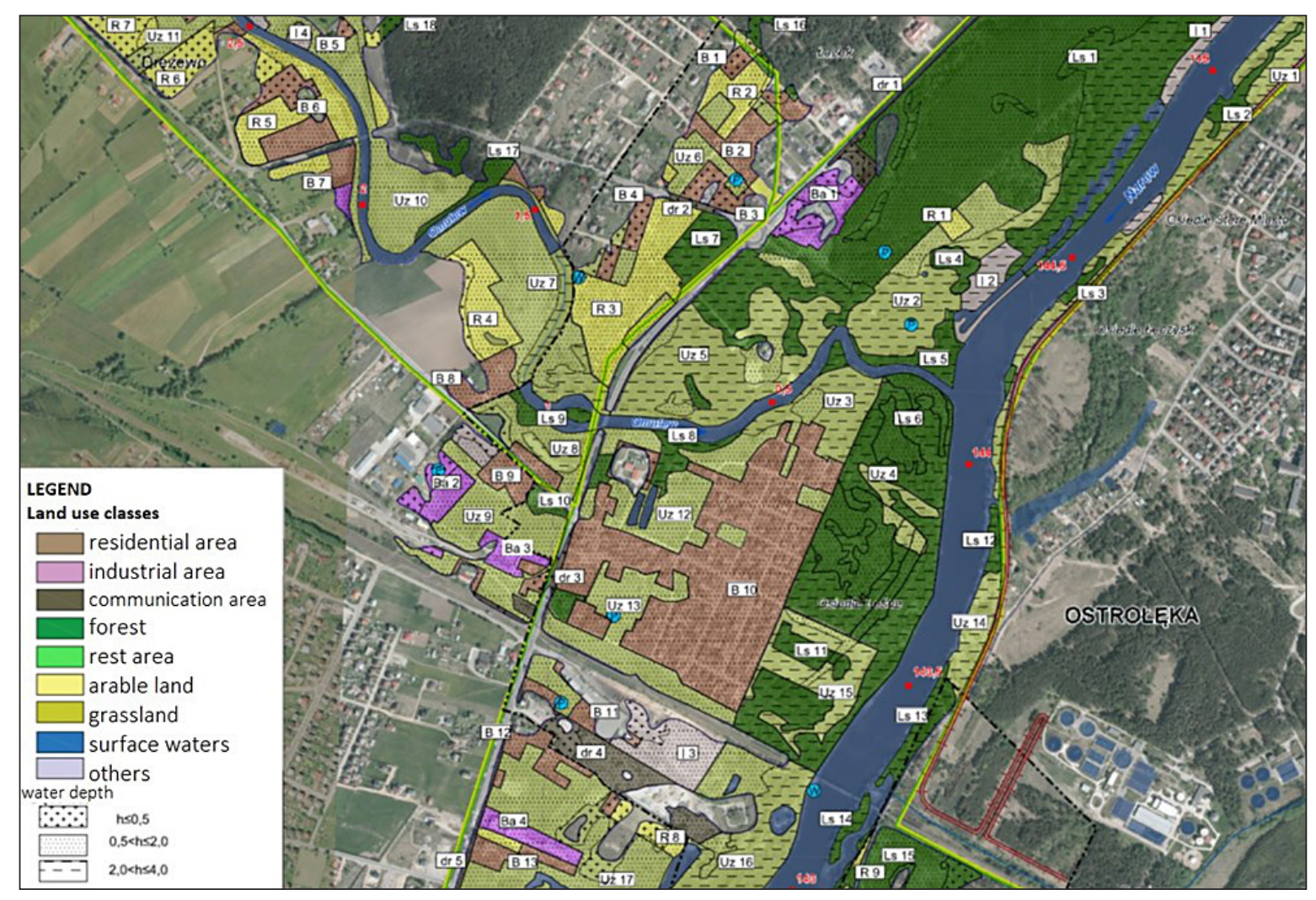

Appendix A. Flood risk map - value ranges of potential flood losses. Areas with an average probability of flooding once every 100 years (based on GUS, 2019)

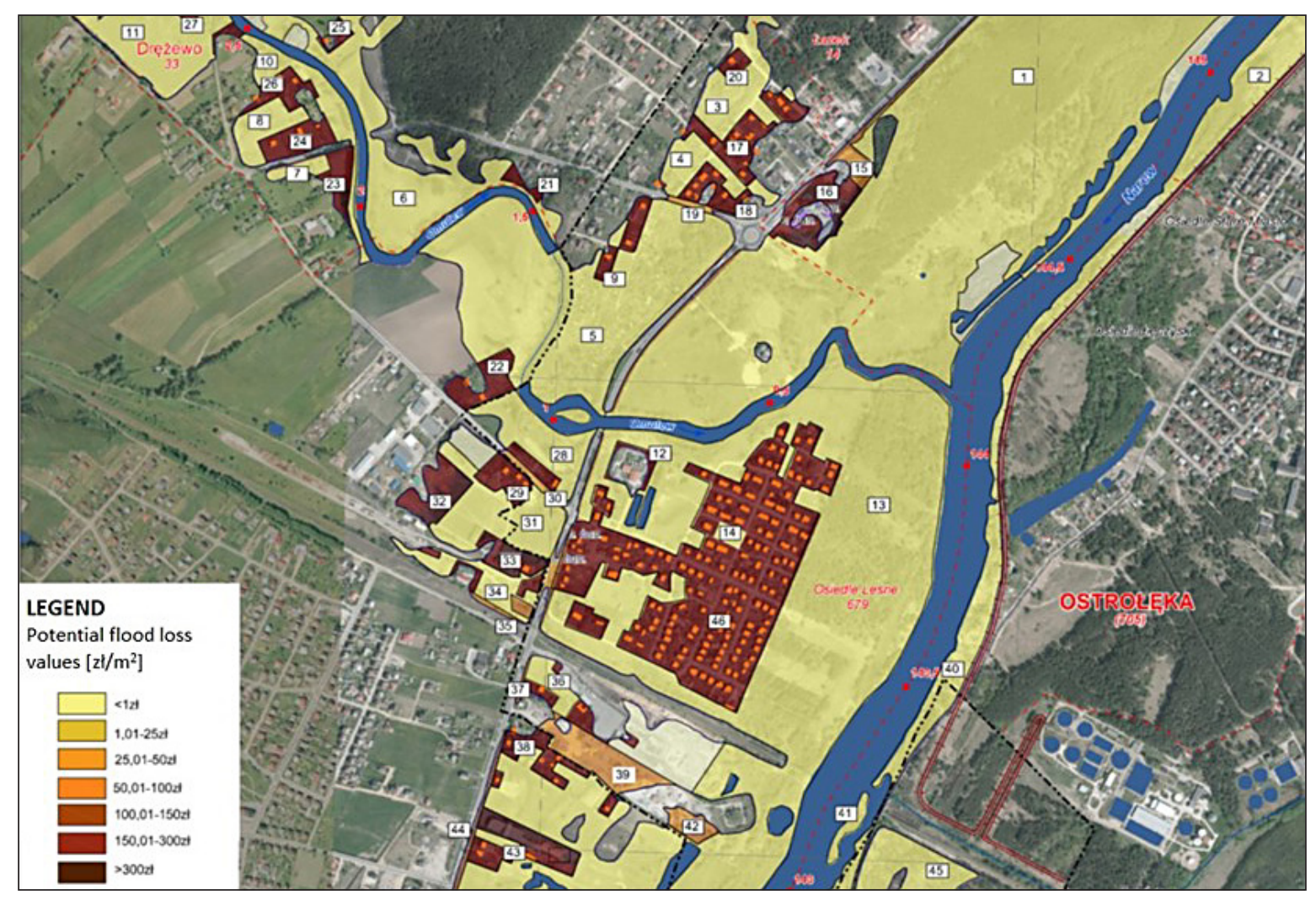

Appendix B. Flood risk map with land use classes and water levels marked. Areas with an average probability of flooding once every 100 years (based on GUS, 2019) 
that our calculations will have. In the regulation, the indicators were developed on the basis of prices and data from 2008; therefore they are out of date in relation to the current reality. A lot has changed in recent years. This paper developed a method to update the indicators and adapt them to the current reality.

The results allowed for drawing the following conclusions:

- the greatest material losses occur in developed areas,

- forest areas suffer the least financial losses,

- the guidelines used when estimating financial losses do not provide the information on the update methods at the time of valuation, thus varied methods and indicators can be used at this stage,

- the loss value in industrial areas should take into account the losses related to current assets, as they make up to $15 \%$ of fixed assets;

- the greatest underestimation due to the updating of prices occurs in the areas used for agriculture, in particular in agricultural areas,

- an increase in the value of losses by over $22 \%$ was observed by updating the value.

The presented method of calculating flood losses shows the significant impact of updating prices on the final result.The value of estimated financial losses can be treated as approximate because the method used does not take into account detailed conditions, such as the standard of housing development or the type of crops on arable land. However, it still enables to illustrate the size of the threat. Estimation of material losses is an important stage to be undertaken by local authorities and residents with reference to the location of new investments. The information concerning the flood and its consequences may also be helpful in crisis management (Ciepielowski, 1999; Egler, 2003).

\section{REFERENCES}

1. Act of 20 July 2017 water law (Journal of Laws, item 310). Available online: http://www.isap.gov. pl (accessed on 6 October 2019).

2. Act of 21 November 2012 on the development of flood risk maps and flood risk maps (Journal of Laws, item 104).Available online: http://isap.sejm.gov. pl/isap.nsf/download.xsp/ WDU20130000104/O/ D20130104 .pdf (accessed on 06-10-2020).

3. BDL. Bank Danych Lokalnych. Available online:
https://bdl.stat.gov.pl/BDL/start (accessed on 15-09-2020)

4. Behnen T., 2000. Der beschleunigte Meeresspiegelanstieg und seine sozioökonomischen Folgen: Eine Untersuchung der Ursachen, methodischen Ansätze und Konsequenzen unter besonderer Berücksichtigung Deutschland, Hannoversche Geographische Arbeiten: Band 54, 54.

5. Best practices on flood prevention, protection and mitigation, Water Directors of EU meeting, Athens, 2003, 6-29.

6. Borowska-Stefańska M., 2014. Ocena ryzyka powodziowego jako element wdrażania Dyrektywy powodziowej - przykład Uniejowa; Problemy Rozwoju Miast. Kwartalnik Naukowy 3, 5-11.

7. Borowska-Stefańska M., 2015. Zagospodarowanie terenów zagrożonych powodziami w województwie łódzkim, Wydawnictwo Uniwersytetu Łódzkiego.

8. Borowska-Stefańska M., 2015a. Ocena potencjalnych strat materialnych na terenach zalewowych, wyznaczonych dwoma metodami w wybranych miastach województwa łódzkiego, Problemy Rozwoju Miast 4, 5-18.

9. Borowska-Stefańska M.,2015b. Zagospodarowanie terenów zagrożonych powodziami w Uniejowie, Biuletyn Uniejowski, Łódź, 132-142.

10. Buczek A., Nachlik E., 2011. Wykorzystanie BDOT w ocenie ryzyka powodziowego problem integracji informacji przestrzennej. Roczniki Geomatyki 9, 6(50), PTIP Warszawa, 26-39.

11. Ciepielowski A., 1999. Podstawy gospodarowania wodą, Wydawnictwo SGGW, Warszawa, 152.

12. Chojnacki J., 1994. Wskaźniki strat powodziowych, Gospodarka Wodna 10, 227-231

13. DEFRA (Department For The Environment, Food and Rural Affairs), Flood and Coastal Defence Project Appraisal Guidance, Part 3: Economic Appraisal, 1999, 25-43.

14. Directive 2007/60/WE of The European Parliament And of The Council of 23 October 2007 on the assessment and management of flood risks. Available online https://eur-lex.europa.eu/ (accessed 20-06-2019).

15. Ebenhöh W., Sterr H., Simmering F., 1997.Potentielle Gefährdung und Vulnerabilität der deutschen Nord- und Ostseeküste bei fortschreitendem Klimawandel, Case Study in Anlehnung an die Common Methodology der IPCC Coastal Zone Management Subgroup.

16. Egler R., 2003. System ochrony przeciwpowodziowej kraju. Part 1. i Cz.2, Płaj, 143-148; 189-197.

17. Ėihák F., Fosumpaur P., Satrapa L., 2005. Methodology for the evaluation of flood defence measures proposed for II. stage of the Flood prevention program, 56-89. 
18. Green C.H., 2003. Evaluating vulnerability and resilience in flood management. [In:] Van Der Veen A., Arellano A.L.V., Nordvik J.P. (Eds.), In Search of a Common Methodology on Damage Estimation, EUR 20997 EN, Ispra: European Commission.

19. Grežo H., Močko M., Izsóff M., Vrbičanová G., Petrovič F., Straňák J., Muchová Z., Slámová M., Olah B., Machar I., 2020. Flood Risk Assessment for the Long-Term Strategic Planning Considering the Placement of Industrial Parks in Slovakia. Sustainability,12(10), 4144; https://doi.org/10.3390/ su12104144

20. Google Maps. Available online: https://www. google.com/maps/place/ (accessed on 20-04-2020)

21. Gutry-Korycka M., Sadurski A., Kundzewicz Z., Pociask-Karteczka J., Skrzypczyk L., 2014. Zasoby wodne i ich wykorzystanie, Nauka 1, 92-95.

22. GUS., 2019. Rocznik statystyczny przemysłu 2019, Główny Urząd Statystyczny, Warszawa.

23. ISOK. Informatyczny System Osłony Kraju. Available online: https://isok.gov.pl/hydroportal.html (accessed on 19-04-2020)

24. Kocur-Bera K., 2016. Uwarunkowania powstawania strat finansowych na obszarach wiejskich powodowanych przez ekstremalne zjawiska pogodowe. Infrastruktura i Ekologia Terenów Wiejskich I/1, 117-130.

25. Kocur-Bera K., 2017. Information (maps, projects) collected for safety space management. Environmental Engineering" 10th International Conference Vilnius, Gediminas Technical University Lithuania, 27-28 April.

26. Kobojek E., 2013. Problem przestrzennego rozwoju miast $\mathrm{w}$ dolinach rzecznych na przykładzie Łowicz i Uniejowa, Uniwersytet Łódzki, Bielsko Biała, 5-18.

27. Messner F., Meyer V., 2005. Flood damage, vulnerability, and risk perception - challenges for flood damage research in Flood Risk Management - Hazards. Vulnerability and Mitigation, 149-167.
28. Mihu-Pintilie A., Cristi Nicu I., 2019. GIS-based Landform Classification of Eneolithic Archaeological Sites in the Plateau-plain Transition Zone (NE Romania): Habitation Practices vs. Flood Hazard Perception. Remote Sensing. 11(8), 915; https://doi. org/10.3390/rs11080915

29. Muszyński R., 2018. Analiza zagrożeń powodziowych na wybranym obszarze, praca magisterska, $25-48$

30. Ristic R., Kostadinov S., Abolmasov B., Dragicevic S., Trivan G. , Radic B., Trifunovic M., Radosavljevic Z., 2012. Torrential floods and town and country planning in Serbia. Natural Hazards Earth System Sciences 12(1), 23.

31. Satrapa L., Fosumpaur P., Horsky M., 2005. Methods of flood damage evaluation, MS-PowerPoint Presentation, 25-39.

32. Schanze J.,Zeman E. and Marsalek J., Management: Hazards, 2006. Vulnerability and Migration Measures, NATO Science Series, Springer Publisher, 25-37.

33. Schultz B., 2008. Water management and flood protection of the polders in the Netherlands under the impact of climate change and man-induced changes in land use. Journal of Water and Land Development 12, 71-94

34. Smith K., 1998. Ward R. Floods - Physical processes and human impacts, Chichester, 142-229

35. Sowiński M., 2008. Szkody powodziowe jako element wyznaczania ryzyka, Polska Akademia Nauk, $\mathrm{Nr} 7 / 2008$.

36. Szeląg B., Cienciała A. ,Sobura Sz., Studziński J., García J.T., 2019. Urbanization and management of the catchment retention in the aspect of operation of storm overflow: A probabilistic approach. Sustainability, 11(13), 3651; https://doi.org/10.3390/su11133651

37. Wałęga A., 2014. Ocena zagrożenia powodziowego w aglomeracji krakowskiej jako element zarządzania ryzykiem powodziowym, Formatio Circumiectus, 13 (4), 259-273. 